\title{
Mobile Learning for Teachers Training in Indonesia: The Potential of Mobile Phones as the Device
}

\author{
Iin Karmila Yusri \\ Politeknik Negeri Ujung Pandang \\ Makassar, South Sulawesi, Indonesia
}

\author{
Robert Goodwin \\ Flinders University \\ Adelaide, South Australia, Australia
}

\author{
Carl Mooney \\ Flinders University \\ Adelaide, South Australia, Australia
}

\begin{abstract}
This paper presents a review on mobile phones, from an Indonesian perspective to investigate the prospect of using mobile phones for mobile learning based training. The review revealed the potential of mobile phones, compared to other mobile devices, to be used as the primary tool in a mobile learning system. In Indonesia, mobile phones are used extensively, and the price for devices and services are affordable for Indonesians. The broad coverage area of the mobile network was also a reason to choose mobile phones as the preferred mobile learning device.
\end{abstract}

Keywords_-mobile learning; mobile phones; device

\section{INTRODUCTION}

Using mobile technologies in learning environments can offer diverse opportunities for educators, and learners, because this technology offers control over learning, mobility regarding time and place, and extensive communication and interaction [1]. The integration of the mobile and wireless computing technology with traditional learning processes is known as mobile learning. A fundamental element of mobile learning is its ability to deliver learning resources to those who may be unable to attend traditional learning environments and provide a practical and personal way to learn [2]

This paper is a part of a research project aimed to develop a model of mobile learning based ICT training for teachers in Indonesia. Teachers in Indonesia have problems in attending training due to time, location, cost, and limited seat availability in a training session [3]. Using mobile technologies in learning can be a solution for teachers' training problems in Indonesia. The research proposed the used of mobile phones for the mobile learning model. Therefore, an investigation on the potential of mobile phones for mobile learning system in Indonesia was conducted.

This paper presents a review of mobile phones usage in learning and the state of mobile phones in Indonesian contexts to investigate the potential of mobile phones to be used as a device in mobile learning in Indonesia.

\section{MOBILE PHONES FOR LEARNING}

Mobile phones are the most widely used device for mobile learning [4]. Mobile phones are ready-at-hand, easy to handle and continuously used in daily activities, enabling users to get to know their own devices. Mobile phones are considerably cheaper and widely available compared to other wireless communication devices [5].

Mobile phones have some features in common, while the differences among them were found to be in the additional functions or quality of the features provided by the manufacturers [6]. The features can be used for a range of learning activities in mobile learning which allows learners to build up a series of personal notes, observations, a collection of evidence and reflections of progress [7].

The results of many of the mobile learning projects suggest that mobile phones are best suited to support language learning [8]. A microprocessor course has been redesigned using a low-cost GSM mobile phone to allow bidirectional interaction between the system, the students, and the lecturer [9]. The results obtained in this study demonstrated the critical role of mobile phones in supporting interactivity and motivating features in a laboratory course.

Mobile phones were also used in some mobile learning projects for teachers. Teacher training projects for teachers in rural areas used 3G mobile phones as a medium of training [10]. Large-scale Teacher Professional Development (TPD) using mobile phones was conducted in Bangladesh [11]. This project showed that cheap mobile phones provided opportunities to deliver TPD and improve teachers' skill.

\section{MOBILE PHONES IN INDONESIA}

Indonesia is a fast-growing market in south-east Asia with around 308.2 million mobile subscriptions [12]. This number was reached because Indonesians tend to have two or three active SIM cards and often own two or three phones. The ownership of multiple SIMs is one of the unique characteristics of Indonesia's mobile users. Most Indonesian use their basic phones for a voice call or SMS, while they used their smartphone for data/internet services [13]. So the number 
of unique users in Indonesia is around 165 million, which means on average each user holds 1.7 active SIM cards.

In 2015, the consensus forecast was that smartphones will represent around $40 \%$ of all handsets and is going to outnumber feature phones by 2017 . However, feature phones will still dominate the installed base of the mobile phone in Indonesia until 2016, despite the rapid growth of smartphones.

People tend to choose feature phones which provide similar features to smartphones but with a lower price. Also, most smartphone users in Indonesia do not optimize the capabilities of their devices [13]. They mainly use primary voice and messaging services such as SMS and Instant Messaging. The internet service of their phone is used just to access social media such as Facebook and Twitter.

\section{The Potential OF Mobile Phones}

Mobile phones have more potential to be used as the medium of training compared to other handheld devices. This section presents the prospect of mobile phones as a tool for mobile learning for teacher training in Indonesia.

\section{A. The extensive use of mobile phones}

In Indonesia, around $83.2 \%$ of household owned mobile phones and $22.2 \%$ of household had access to the internet. The majority of internet users in Indonesia accessed the internet through their mobile phones [12]. Using the internet via mobile phones is considered more economical than via a computer.

The price of a mobile phone is a significant factor in the rapid adoption of mobile phones in developing countries [14]. Mobile phones are cheaper than other handheld devices. From 2000 to 2010 , mobile phone prices have decreased by a further $22 \%$ in developing countries [15].

By the end of 2015, global penetration of mobile phone subscriptions was expected to be 96.8 per 100 inhabitants [16]. In Indonesia, mobile phone penetration increased at an exponential rate over the period from 2000 to 2014, from 1.76 to 126.18 cellular phone subscriptions per 100 inhabitants [17].

\section{B. Low-cost services}

The prices of mobile-cellular services are considered cheap, and the prices have contributed to the widespread adoption of voice and SMS services [18]. By the end of 2013, a low-usage prepaid mobile-cellular service cost on average 1.6 percent of Gross National Index (GNI) per capita (p.c.) in developed countries, as against 6.2 percent in developing countries [18]. The price of mobile cellular service in Indonesia was USD 6.86. Compared to its neighbors, the price in Indonesia was considered low.

According to [18], Indonesian mobile cellular services cost around $2.30 \%$ of their GNI p.c. The price was considered affordable for Indonesians because the percentage of the price cost GNI p.c. is less than the average mobile-cellular service cost in developing countries. Also, the affordability target set by the Broadband Commission for Digital Development
(BCDD) for broadband prices was less than $5 \%$ of GNI p.c. by 2015 , and Indonesia has fulfilled the target with only $2.30 \%$.

\section{Wide coverage area}

With the wide coverage area of the mobile network, mobile phones can be used in most places. In 2010, around $90 \%$ of the world population had available access to mobile networks, with $80 \%$ in rural areas [15] and $95 \%$ of the world population was covered by a $2 \mathrm{G}$ mobile-cellular network [16].

The coverage area of cellular operators in Indonesia can be determined by the number of Base Transceiver Station (BTS) owned by the operators. In 2014, Telkomsel has 46,398 2G BTS and 39,022 3G BTS [19]. Meanwhile, Indosat has 22,166 $2 \mathrm{G}$ BTS and 18,603 3G BTS, and XL has 20,607 2G BTS and $39,0063 \mathrm{G}$ BTS. One BTS can usually serve several mobile stations at a distance radius of about $5 \mathrm{~km}$ [20].

By the middle of 2013, the Telkomsel network was already available in all provinces in Indonesia followed by XL that served 30 provinces, Indosat and Three-Hutchinson reached customers in 22 and 21 provinces respectively, and Smartfren was accessible in 13 provinces [21].

\section{CONCLUSIONS AND Future Works}

Mobile phones have more potential to be used as the medium of training compared to other handheld devices. This paper presents the prospect of mobile phones as a tool for mobile learning for teacher training in Indonesia.

In Indonesia, mobile phones have more potential to be used as the primary tool in mobile learning than other mobile devices. The first reason is that almost all Indonesian have access to mobile phones. Secondly, the price of mobile phones and the services are considered affordable for Indonesians. Lastly, a mobile phone is the only mobile device that can be used everywhere in Indonesia, including in rural and borderline areas.

Future work will involve a study to investigate teachers' readiness to engage in mobile learning for training using mobile phones.

\section{References}

[1] J. Traxler, "Current state of mobile learning," Mob. Learn. Transform. Deliv. Educ. Train., vol. 1, pp. 9-24, 2009.

[2] C. Locke, "M-Learning: A platform for educational opportunities at the base of the pyramid," GSMA Dev. Fund. Retrieved January, vol. 5, p. 2013, 2010.

[3] I. K. Yusri and R. Goodwin, "Mobile learning for ICT training: Enhancing ICT skill of teachers in Indonesia," Int. J. e-Education, eBusiness, e-Management e-Learning, vol. 3, no. 4, p. 293, 2013.

[4] P.-H. Wu, G.-J. Hwang, L.-H. Su, and Y.-M. Huang, "A context-aware mobile learning system for supporting cognitive apprenticeships in nursing skills training.," Educ. Technol. Soc., vol. 15, no. 1, pp. 223236, 2012.

[5] J. Traxler and A. Kukulska-Julme, "Mobile learning in developing countries." Commonwealth of Learning, Vancouver, 2005.

[6] G. Goggin, Cell phone culture: Mobile technology in everyday life. Routledge, 2012. 
[7] C. P. Schofield, T. West, and E. Taylor, "Going mobile in executive education," UNICON Exec. Educ. Consort., 2011.

[8] N. Cavus and D. Ibrahim, "m-Learning: An experiment in using SMS to support learning new English language words," Br. J. Educ. Technol., vol. 40, no. 1, pp. 78-91, 2009.

[9] M. del R. Martínez-Torres, S. L. Toral, F. Barrero, and S. Gallardo, "Improving learning performance in laboratory instruction by means of SMS messaging," Innov. Educ. Teach. Int., vol. 44, no. 4, pp. 409-422, 2007.

[10] Y. Zhang and J. Li, "Application of 3G-based mobile learning in teacher training," in Information and Computing (ICIC), 2011 Fourth International Conference on, 2011, pp. 27-29.

[11] C. S. Walsh, R. Shaheen, T. Power, C. Hedges, M. Katoon, and S. Mondol, "Low cost mobile phones for large scale teacher professional development in Bangladesh," 2012.

[12] S. Kemp, "We are social's compendium of global digital statistics," Digit. Soc. Mob. 2015, 2015.

[13] D. Widhyatmoko, "Ponsel Lebih Dari Sekedar Alat Komunikasi," Humaniora, pp. 360-367, 2011.

[14] R. A. Onyango, R. W. Ongus, F. M. Awuor, and C. Nyamboga, "Impact of Adoption and Use of Mobile Phone Technology on the Performance of Micro and Small Enterprises in Kisii Municipality Kenya," World $J$. Comput. Appl. Technol., vol. 2, no. 2, pp. 34-42, 2014.

[15] I. T. Union, The World in 2011: ICT Facts and Figures. ITU, 2011.

[16] A. van Heerden, M. Tomlinson, and L. Swartz, "Point of care in your pocket: a research agenda for the field of m-health," Bull. World Health Organ., vol. 90, no. 5, pp. 393-394, 2012.

[17] T. Union, "International Telecommunication Union," Yearb. Stat. 19912000, 2001.

[18] U. internationale des télécommunications, Measuring the Information Society Report 2014. International telecommunications union, 2014.

[19] P. Dunleavy, Digital era governance: IT corporations, the state, and egovernment. Oxford University Press, 2006.

[20] T. A. Nugroho, "Remote Monitoring Berbasis GPRS (Studi Kasus: Monitoring Shelter BTS)," in Seminar Nasional Aplikasi Teknologi Informasi (SNATI), 2010.

[21] K. Informasi, “Komunikasi.(2012)," Data Stat. Bid. Pos dan Telekomun. 